\title{
Leaf litter degradation in the wave impact zone of a pre-alpine lake
}

\author{
Simone Pabst • Nicole Scheifhacken • \\ John Hesselschwerdt $\cdot$ Karl M. Wantzen
}

\begin{abstract}
Contrary to streams, decomposition processes of terrestrial leaf litter are still poorly understood in lakes. Here, we examined the decomposition of two leaf species, beech (Fagus sylvatica) and poplar (Populus nigra 'italica') in the littoral zone of a large pre-alpine lake at a wave exposed site. We focussed on the shredding impact of benthic invertebrates in a field experiment and on the effects of wave-induced disturbances under field and mesocosm conditions. In contrast to our expectations, benthic shredders did not reveal an important role in leaf processing under the conditions of the field experiment (early spring time, wave impact zone). Strong wave turbulence during storm events significantly reduced leaf mass, FPOM and invertebrate densities at field conditions. Several reasons can explain the low importance of shredders in our field study: (a) phenology of the shredder species, (b) feeding preferences and alternative food sources for gammarids, (c) generally low abundance of the native gammarid species due to the recent occurrence of an invasive predator, (d) disturbance of shredder activity
\end{abstract}

Guest editors: K. M. Wantzen, K. O. Rothhaupt, M. Mörtl, M. Cantonati, L. G. Tóth \& P. Fischer

Ecological Effects of Water Level Fluctuations in Lakes

S. Pabst $\cdot$ N. Scheifhacken $\cdot$ J. Hesselschwerdt .

K. M. Wantzen ( $\square)$

Limnologisches Institut, Universität Konstanz, Mainaustraße 212, 78464 Constance, Germany

e mail: matthias.wantzen@uni konstanz.de due to high wave impact and (e) relatively low food value of the offered leaves. We suggest that leaf litter decomposition in lakes occurs in specific process domains, which largely depend on the hydraulic characteristics and on water-level fluctuations.

Keywords Decomposition - Leaf hardness · Benthic invertebrates - Aquatic fungi . Hydrodynamics $\cdot$ Mesocosm $\cdot$ Littoral . Ergosterol

\section{Introduction}

In running water ecology, leaf litter is generally accepted to represent an important allochthonous carbon source for canopy-shaded streams, e.g. in the northern temperate zone (Wallace et al., 1997). In lakes, this situation may be different. Litter inputs vary considerably with the type of aquatic-terrestrial linkages. Little is yet known about allochthonous litter inputs via the littoral zone, about the organisms using the carbon deriving from these inputs and about the fate of the degraded leaves. Studies from oligo-mesotrophic lakes in SE Sweden have shown a very intensive input of leaf material, the carbon of which is then transferred to the bacteria (Bohmann \& Tranvik, 2001) and benthic invertebrate shredders (Bjelke et al., 2005). Similar to northern temperate streams (Grubbs \& Cummins, 1996; Wantzen \& Wagner, 2006), aquatic insects, especially 
Limnephilidae (Trichoptera), were the most important shredders in these lakes, and they showed an apparent temporal pattern of winter and summer growing species that were specialised on different litter types (Bjelke et al., 2005). The "winter shredders" began their life cycle during the autumnal leaf fall and used the freshly fallen leaf material of fast-degrading species as food source, while the "summer shredders" used a mixture of processed, more recalcitrant leaves and additional food sources.

In the same Swedish lakes, the natural decomposition rate of the most common leaf litter types (Betula pendula and Quercus robur) were rather fast and the leaves were processed after 36 months (Bohmann \& Hermann, 2006). Although the shredding activity released little dissolved organic matter (DOM) in addition to the passive initial leaching, the bacterial production in the water was enhanced by shredders (Bohmann \& Tranvik, 2001).

In a study on a small eutrophic lake in Wisconsin, USA, Gasith \& Hasler (1976) suggested that in oligotrophic and small eutrophic lakes, about $10 \%$ of the organic carbon budget were derived from airborne litter, and more than $80 \%$ of the litterfall consisted of leaves. They pointed out that the density of terrestrial vegetation along the shore and the shore length strongly determine the magnitude of transport of the airborne litterfall into lakes. For similar lacustrine systems, Gasith \& Hasler (1976) estimated a maximum annual transport of airborne litterfall of $500 \mathrm{~g} \mathrm{C}$ per $\mathrm{m}$ shoreline. In a study in Lake Stechlin (NE Germany), Casper (1987) calculated a dry-mass input from beech trees that cover nearly the whole lake shore to $1,111 \mathrm{~g} \mathrm{C}$ per $\mathrm{m}$ shoreline and year. Considering that most of the leaves become sedimented in the upper littoral of Lake Stechlin, this amount increased the sedimentation rate from 30 to 152 $\mathrm{mg} \mathrm{C} \mathrm{m}{ }^{-2} \mathrm{~d}^{-1}$ (not considering macrophytes). Interestingly, the decomposition rate of beech leaves did not vary between Lake Stechlin and acidic or eutrophic lakes (Casper, 1990). Gasith \& Lawacz (1976) also investigated the breakdown rate of five different leaf species in a eutrophic lake and found similar leaf processing rates in lotic and lacustrine systems for some species. They concluded that the efficiency of the two systems in decomposing leaf litter is comparable even though the contribution of the biotic and abiotic factors affecting the breakdown may be different.

In pre-alpine lakes of Europe, most decomposition studies have focussed on reed, Phragmites australis, which contributes to large parts of the primary production and organic carbon budgets of the littoral zone (Gessner et al., 1996; Gessner, 2000, Kominkova et al., 2000). It is currently unknown to which degree allochthonous leaf litter from trees contributes to the carbon budget, neither do we know which factors influence the decomposition process in these lakes. A large variability of these processes can be expected. Reed belts are known to be efficient mechanical filters for lateral coarse particulate organic matter (CPOM) inputs, and many shore areas have been colonised and deforested, and therefore, tree litter inputs occur only in selected areas. The morphology of the littoral zone varies greatly between shallow and vertical slopes, with a wide range of hydraulic conditions and substrate types, including the respective benthic invertebrate assemblages (Scheifhacken et al., 2007). Moreover, species-specific characteristics of the leaves (e.g. leaf hardness and plant secondary compounds) influence the microbial attack and shredding by invertebrates (Wantzen et al., 2002).

Natural pre-alpine lakes have water-level fluctuations (due to freezing of the tributaries in winter and snowmelt and rain inputs in early summer) that completely change the hydraulic situation in the upper littoral zone where most of the decomposition is supposed to take place. The wave impact zone and the layer where the strongest shear stress occurs move along the aquatic-terrestrial transition zone (ATTZ) during the annual water-level fluctuations. Contrary to streams, the direction of the water movement is hard to predict in the wave zone of the littoral as it changes with water level, internal seiches, wind impact, thermal currents and waves caused by ships. The impact of water movement on the mechanical destruction of organic matter in the lake littoral is currently unknown.

In the present study, we examined, for the first time, the decomposition of terrestrial leaf litter in the littoral zone of a large, deep pre-alpine lake, Lake Constance $\left(47^{\circ} 39^{\prime} \mathrm{N}, 9^{\circ} 18^{\prime} \mathrm{E}\right)$. We focussed on the natural processing of the leaf litter under field conditions and in standardised mesocosm experiments with controlled wave impact. We used leaves of two tree species that are common at European lakeshores and have different leaf characteristics. Beech (Fagus sylvatica) is more recalcitrant to decomposition than poplar (Populus nigra 'italica') in streams. Studies in lotic ecosystems reported $-k$ values of 0.0018 for beech and 0.0091 for poplar (Baldy et al., 1995; 
Dangles \& Guérold, 1998). Therefore, we hypothesised that poplar leaves would be processed faster than beech in the lake, too, and we expected that the colonisation process by benthic invertebrates and the importance of shredders for leaf decomposition would vary according to leaf type. We further expected that the underlying hydrodynamic conditions of the lake littoral zone, i.e. wave action, are important to break up the leaves and therefore to accelerate decomposition. Effects of wave action on the decomposition rates of the leaves were studied under natural exposure conditions and in mesocosms that allowed to compare a defined wave action with a no-wavecontrol treatment.

\section{Methods}

Site of the field experiment

The field experiment was performed in the 'Littoral garden', a leeward erosion bank with a wide boulder shore on the south-western shore of the Überlingen Basin, a part of Upper Lake Constance (Fig. 1). Lake Constance is an oligotrophic pre-alpine lake $(10 \mu \mathrm{g} \mathrm{P}$ $1^{-1}$ during spring circulation) with a surface of $473 \mathrm{~km}^{2}$, a mean depth of $101 \mathrm{~m}$ and a maximum depth of $254 \mathrm{~m}$. The water level normally fluctuates by about $2 \mathrm{~m}$ every year, with a minimum water level in the winter and a maximum in the summer months, triggered by melting water runoff in the Alps (Luft \& Vieser, 1990). At mean water level, about $15 \%$ of the area is shallow water less than 10-m deep and is therefore classified as a littoral zone (IGKB, 2004). Westerly winds prevail throughout the year, with a second less-dominant peak of easterly winds especially in winter (Bäuerle et al., 1998). Along the 186-km shoreline of Upper Lake Constance, the littoral zone varies greatly in width, sediment composition and wind exposure. The study site is characterised by regular wave action caused by ferries and leisure boats. The littoral sediment of this place consists mainly of siltish sands with a more-or-less packed stony overlay (Schmieder et al., 2004). The shore vegetation contains mainly native trees such as beech, poplar and oak.

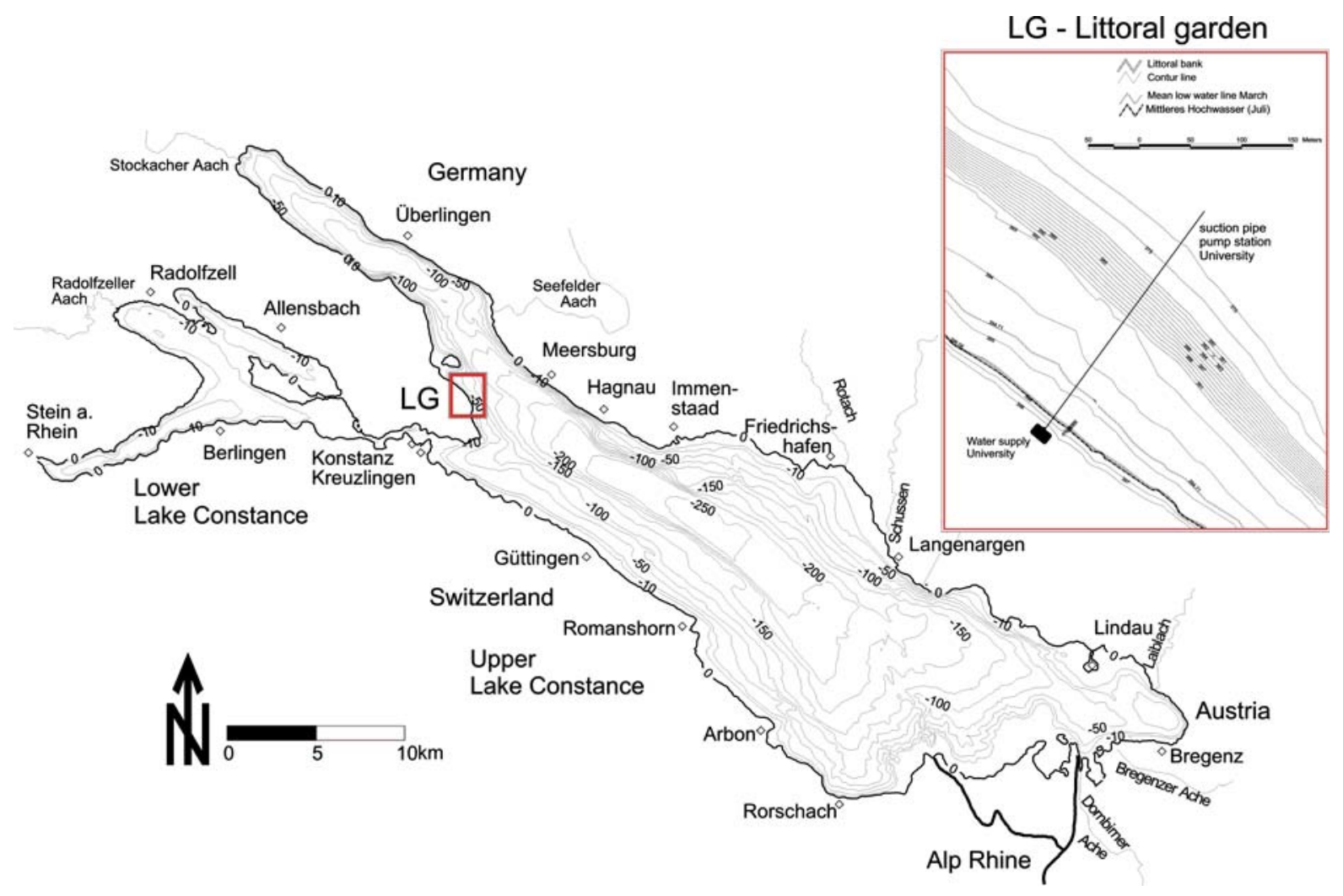

Fig. 1 Experimental field site 'Littoral garden' LG at Upper Lake Constance 
Litterbags

Both field and mesocosm experiments were conducted with leaves of beech (Fagus sylvatica) and poplar (Populus nigra 'italica'), collected with an aboveground mounted nylon net near the study site just after abscission in October/November 2004. The leaves were air-dried and stored at room temperature until the beginning of the experiments in winter/ spring 2005. For the field experiment, leaves were placed in nylon litterbags of $15 \times 15 \mathrm{~cm}$ and $4-\mathrm{mm}$ mesh size. The bags were filled with $5 \pm 0.01 \mathrm{~g}$ leaf air-dried weight. The mean correction factor of leaf weight loss was calculated for precise weight loss analysis from air-dried to oven-dry weight $\left(105^{\circ} \mathrm{C}, 15\right.$ subsamples per tree species).

At field, all litterbags of beech and poplar leaves were fixed randomly at a metal square cage $(1 \times 1 \times$ $0.5 \mathrm{~m}$, mesh width $4 \mathrm{~cm}$ ). In order to avoid sedimentation on the litterbags, they were tethered about $15 \mathrm{~cm}$ above the sediment surface, and access by crawling invertebrates from the bottom was possible as the lower end of the bags touched the ground. The cage was tightly anchored in the sediment with $40-\mathrm{cm}$ pegs at each corner to withstand wave action at the site. All litterbags were exposed in February 2005 at 0.4-m water depth. Due to severe storm events, some beech litterbags were lost. Three to five randomly chosen samples per leaf species and date were retrieved after $1,2,7,14,27,42,55$ and 84 days for the determination of weight loss, accumulation of FPOM and status of colonisation with benthic invertebrates. Loss of invertebrates and FPOM during sampling was avoided by placing the litterbags into plastic bags before detaching them from the metal cage. Another three replicates per date were taken for ergosterol analysis from separate litterbags, which were filled with double amount of leaves ( $10 \mathrm{~g}$ dry weight) to ensure sufficient material even after several weeks of decomposition.

\section{Abiotic parameters}

Wind speed and wind direction were obtained from the nearby weather station in Constance-Egg. The maximum wave height and wave period were continuously measured using an acoustic doppler velocity meter (ADV meter) in 2-m water depth at the study site (Hofmann et al., unpublished data). In order to compensate the methodological constraints of ADV in very shallow water depths, we used the dissolution rate of gypsum spheres to characterise the hydrodynamic turbulences near the litterbags, following a standardised procedure (Scheifhacken 2006, Scheifhacken et al., 2007). This method was successfully used in a variety of aquatic environments (e.g. Petticrew \& Kalff, 1991; Angradi \& Hood, 1998; but see also Porter et al., 2000 and cited references therein). The weight loss of five gypsum spheres was determined weekly, thereby integrating overall wave exposure of the site for the given time period. Water temperature was continuously recorded using Minilog data loggers (Vemco, Canada) next to the litterbags. In addition, conductivity, $\mathrm{pH}$ and dissolved oxygen were measured in situ weekly using a portable WTW logger (Multiline F/SET 3, Weilheim, Germany).

Wave mesocosm experiment

The impact of hydrodynamics on leaf processing was studied under standardised mesocosm conditions without adding invertebrates. Two treatments (wave and control) were tested in concrete basins (10-m length, 1-m width, 1-m height). Each basin was equipped with an artificial littoral zone at one side that was made of a metal grid, covered with aquarium foil and a thin layer of substrate coverage $(10 \mathrm{~cm}$, cobble stone) to mimic natural field conditions (slope, substrate roughness, wave shear stress), as described in Scheifhacken (2006), Scheifhacken et al., 2007). The water level was maintained at $0.8-\mathrm{m}$ depth by adding water (2 $2.51 \mathrm{~min}^{-1}$ ) to compensate for evaporation loss.

Wave action in the 'wave mesocosm' was generated by pneumatically moved paddles $(0.9 \times 0.5 \mathrm{~m})$ by employing a specifically designed and selfconstructed pneumatic wave machine (Scheifhacken 2006; Stoll et al., 2008). The 'control mesocosm' lacked waves. Wave duration was regulated through a time switch gear at regular intervals adjusted to the intervals of current ferry timetables at Lake Constance. In the field site of our study, waves caused by ferries are the most important hydraulical impact. During the day (6 am to $9 \mathrm{pm}$ ), wave intervals of 2.5-min duration were followed by a 5 -min pause ( 8 times per hour). During the night, the frequency of wave occurrence was reduced to half of the daytime. 
The two mesocosms were filled with filtered lake water ( $300 \mu \mathrm{m}$ mesh). Abiotic water quality parameters were measured in the same way as in the field experiment. In the control and wave mesocosm, 120 separately weighed $( \pm 0.1 \mathrm{mg})$ and marked leaves, 60 per species (beech and poplar), were arranged in two baskets. These baskets contained four identical compartments $(25 \times 15 \times 15 \mathrm{~cm})$ filled with a gravel layer of the same grain size as found in the littoral sediment. The front and back sides of these units were covered with a wide mesh (4-mm mesh size, polyester, 0.8 -mm fibre) to allow maximum wave action but to hinder leaves from floating within the whole mesocosm. In both mesocosms, the baskets were exposed in 0.4-m water depth. The mesocosm experiment was conducted from midMay to the end of June to avoid freezing periods. Similar to the field experiment, the leaves were retrieved in the time series of 1, 7, 14, 21, 27 and 42 days (five replicates). A longer exposition was not possible due to the tight time schedule for the use of the mesocosms.

\section{Sample processing}

The content of the litterbags was wet-sieved with a set of sieves $(6,300 ; 250 ; 63 \mu \mathrm{m})$ using $50-\mu \mathrm{m}$ filtered lake water. The remainder of the $6,300-\mu \mathrm{m}$ mesh sieve were defined as "whole leaves". The broken leaf parts of the $250-\mu \mathrm{m}$ fraction was later added to the leaf fraction for dry weight analysis. We designated the remaining fraction smaller than $250 \mu \mathrm{m}$ and larger than $63 \mu \mathrm{m}$ as FPOM. All benthic macroinvertebrates were collected from $250-\mu \mathrm{m}$ mesh size fraction and preserved in $70 \%$ ethanol. Additionally, the tiny invertebrates (mainly dipteran first instar larvae), were picked out of the finest fraction using a dissection microscope (Zeiss, Stemi DV4) when possible. In the samples of the last date, there were too many individuals so that about $2 / 3$ of them were left in the FPOM fraction. All invertebrates were identified to the species level if possible, and otherwise, to the nearest taxonomic level, and counted. The assignment of invertebrate taxa to functional feeding groups (FFG) was made according to Moog (2002). All taxa, which at least partly feed on coarse organic matter, were classified as shredders.

\section{Determination of leaf degradation}

The dry weight (DW) of all leaf samples and the FPOM fraction was obtained using drying chambers $\left(105^{\circ} \mathrm{C}\right)$.
One aliquot of $250 \mathrm{mg}$ from the coarse leaf fraction was pulverised and combusted in a muffle furnace at $550^{\circ} \mathrm{C}$ for $5 \mathrm{~h}$ to determine the ash-free dry weight (AFDW), the FPOM fraction was completely combusted. Further, five leaves of each litterbag were air-dried for leaf hardness determination, but afterwards added to the leaf fraction and treated as described above (DW, AFDW).

Leaf hardness was determined from re-moistened air-dried leaves in a water saturated atmosphere. The penetrometer that we used to measure the hardness of leaves was developed by the Max Planck-Institute for Limnology in Plön, by adapting a piercing device to a commercial mechanical pressure meter (Hahn+Kolb GmbH, Stuttgart). The leaf hardness is measured as the maximum counter-force (measured in Newton, N) of a leaf opposing and withstanding a small penetrating metallic bolt ( \& Zimmer (2005) for a current review on the method.

The litter breakdown was determined by calculating a decay coefficient $k_{\text {day }}$ for both leaf types using the exponential regression formula $M_{t}=M_{0} * \mathrm{e}^{-k t}$ according to Petersen \& Cummins (1974).

\section{Ergosterol concentrations}

The decomposed leaf material was frozen at $-30^{\circ} \mathrm{C}$ after sampling until measurement. Determination of ergosterol was done by high-performance liquid chromatography (HPLC, see Gessner (2005) and Gessner \& Schmitt (1996) for a detailed description). For analyses, the leaf material was lyophilised and ground. The extraction was done in alkaline methanol at $80^{\circ} \mathrm{C}$. Solidphase extraction through $\mathrm{C} 18$ cartridges was used for purification. Dry, unprocessed leaves were used for blank values. This material was stored dry at room temperature. In addition to ergosterol concentration, we calculated the biomass of hyphomycetes at the peak time with the conversion factor of $5.5 \mathrm{mg}$ ergosterol $\mathrm{g}^{-1}$ fungal biomass according to Gessner \& Chauvet (1993).

\section{Data treatment}

Effects of sampling date and leaf species on remaining leaf mass or leaf hardness were analysed with two-way ANOVA (Bonferroni corrected) using SPSS 11.0 (SPSS, Chigago, IL) software. Variances were stabilised with $\log (x+1)$ transformation and tested for homogeneity with the Levene test; normality was tested with Kolmogorov Smirnov test (Lozán \& 
Kausch, 1998). Tukey HSD post-hoc tests were applied when significant effects were detected. Nonmetric Kruskal Wallis-test and Mann Whitney- $U$-test were applied when assumptions of variance homogeneity failed after transformation, e.g. for ergosterol and FPOM data. The colonisation process of leaf litterbags by invertebrates was analysed with nonparametric tests using abundance data, number of taxa as well as the Margalef species richness and Pielou's eveness (mean \pm SD) as diversity parameters. In order to detect the dependences of species richness and eveness in terms of exposure time, we used the Spearman rank correlation coefficient (Köhler et al., 1996). Further, benthic community composition was examined with non-metric multidimensional scaling (nMDS) using the PRIMER 6 software (Clarke \& Warwick, 2001). Abundance data (non-transformed) were displayed in nMDS plots using Bray Curtis index for similarity calculations. A priori defined groups (leaf taxa, sampling date) were tested with ANOSIM (analysis of similarities) permutation statistics against random distribution (Clarke \& Warwick, 2001).

\section{Results}

\section{Abiotic parameters}

The mean wave height during the field experiment was $0.07 \mathrm{~m}( \pm 0.06 \mathrm{~m} \mathrm{SD})$. However, two distinct storm events were recorded in the end of February (days 1113 after exposure) and in mid-May (days 54 55; indicated by arrows in Fig. 2), both occurring from eastern directions with maximum wave heights of 0.64 and $0.55 \mathrm{~m}$, respectively. The gypsum dissolution method also registered these events as highly significant (ANOVA: $F_{10,44}=532.66, P<$ 0.001), however, in different magnitudes (see Fig. 2c). The daily mean water temperature $( \pm S D)$ ranged from $3.1 \pm 3.1^{\circ} \mathrm{C}$ to $13.6 \pm 1.3^{\circ} \mathrm{C}$ (Fig. $2 \mathrm{~d}$ ). Mean conductivity was $327 \pm 8 \mu \mathrm{S} / \mathrm{cm}$ (mean $\pm \mathrm{SD}$ ) and mean $\mathrm{pH}$ was $8.5 \pm 0.1$. The water was always saturated with oxygen $(12.7 \pm 0.9 \mathrm{mg} / \mathrm{l})$.

Mass loss, FPOM accumulation, ergosterol content and leaf hardness

After the storm events (Fig. 3a, arrows), the mass loss of poplar was significantly higher than during the
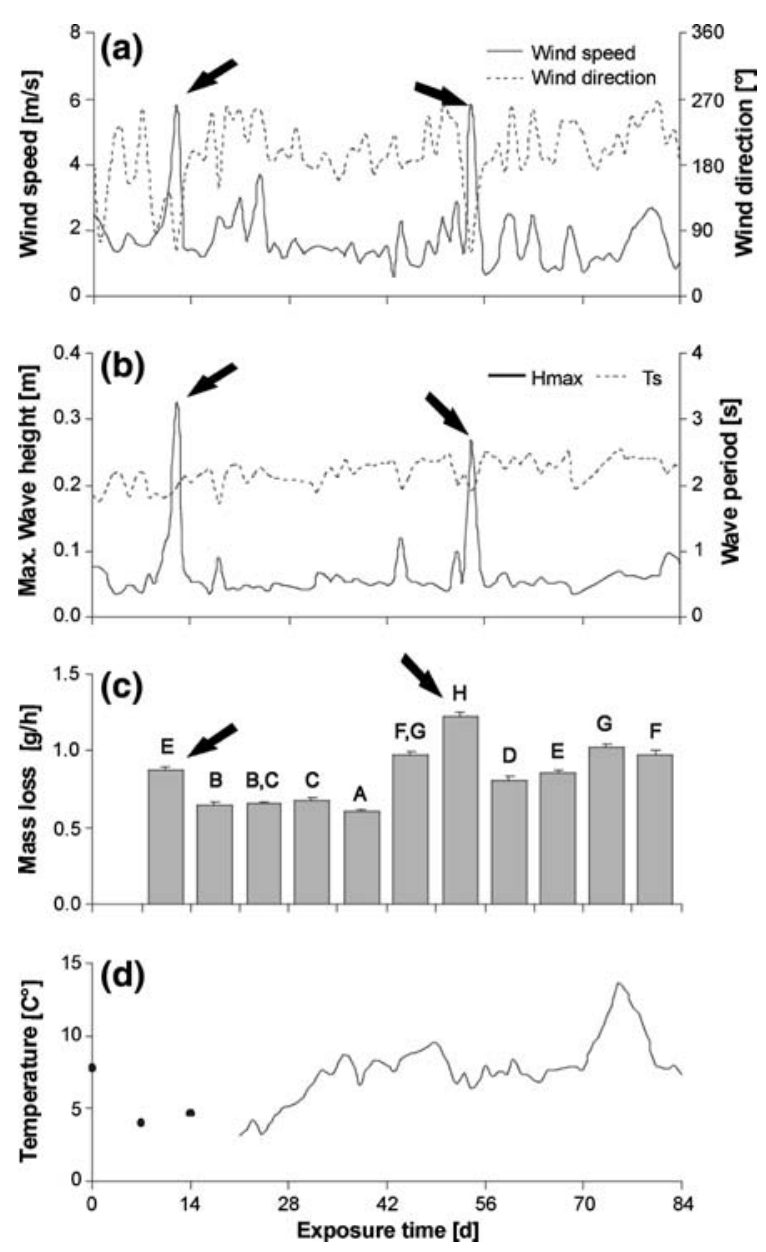

Fig. 2 Measurement of water temperature, hydrodynamic and wind parameters daily means (a), (b) and (d) weekly means (c). (a) Wind speed $(\mathrm{m} / \mathrm{s})$ and wind direction $\left(0^{\circ}=\mathrm{N}, 90^{\circ}=\mathrm{E}\right.$, $\left.180^{\circ}=\mathrm{S}, 270^{\circ}=\mathrm{W}\right)$. (b) Maximum wave height $\left(H_{\max }\right)$ and wave period $\left(T_{\mathrm{s}}\right)$, both measured with an ADV meter. (c) Mean mass loss of plaster balls exposed in the littoral of Lake Constance $(\mathrm{g} / \mathrm{h})$, vertical bars denote positive standard deviation (SD), $n=5$. Values with the same capital letter are not significantly different (Tukey HSD post hoc test). Arrows mark the two extraordinary incidents of storm events from NE directions. (d) Daily mean water temperature $\left({ }^{\circ} \mathrm{C}\right)$. During the first 3 weeks, temperature was measured only once a week (symbols)

other periods (Fig. 3a). The mass loss of beech was only higher after the first storm event although the differences were not significant (Tukey HSD posthoc test, see Fig. 3a). The littoral process of leaf decay revealed a first short phase with rapid mass loss (leaching) and a second longer phase with a moderate decay (Fig. 3a). In the first $24 \mathrm{~h}$, poplar lost $16 \%$, whereas beech only lost $5 \%$ of the initial AFDW. The 

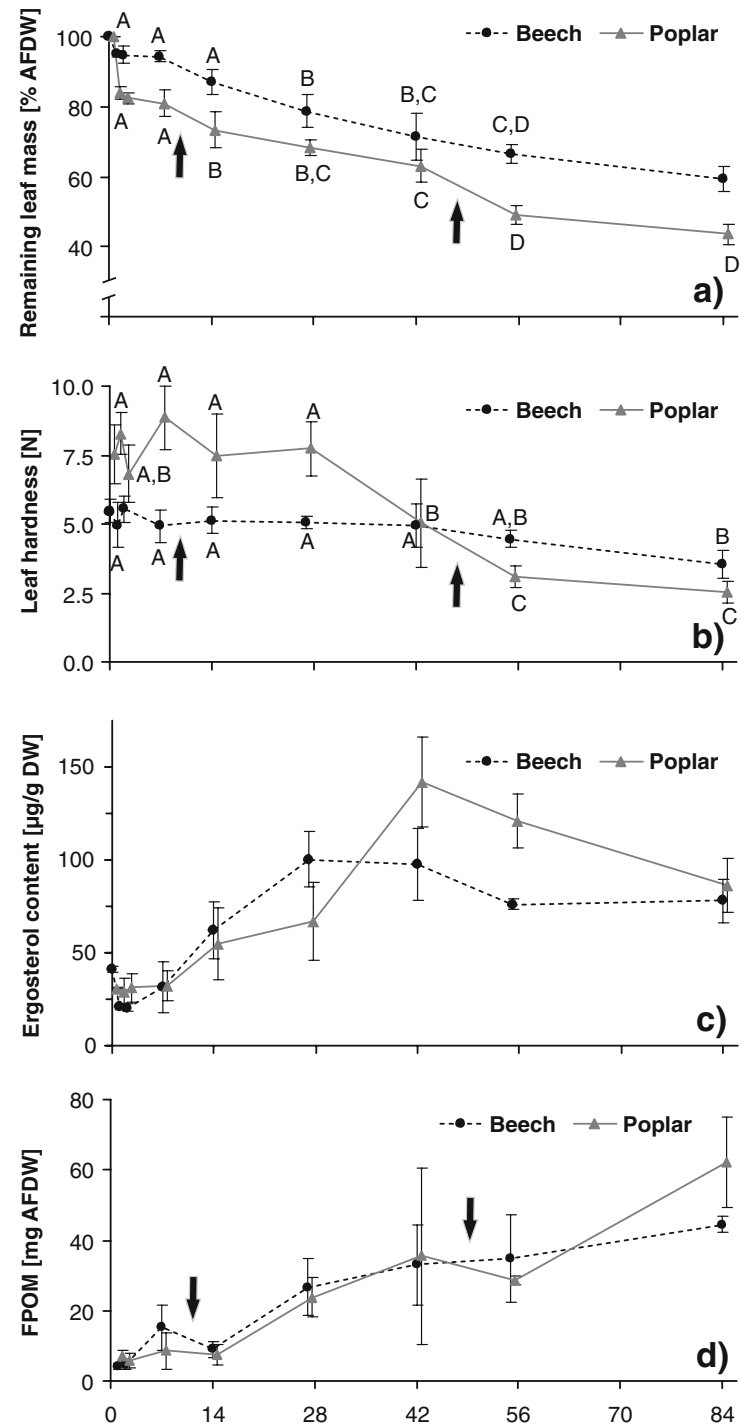

Fig. 3 Degradation rates of leaf mass, leaf hardness and FPOM accumulation over exposure time. Arrows mark the two extraordinary incidents of storm events. (a) Average leaf decay expressed as remaining mass of leaves in \% AFDW referring to initial leaf mass. (b) Mean change in leaf hardness (N). (c) Mean change in ergosterol content of the leaves $(\mu \mathrm{g} / \mathrm{g} \mathrm{DW})$. (d) Mean change in FPOM accumulation (mg AFDW) in litterbags. Symbols and vertical bars indicate mean $\pm \mathrm{SD}, n=35$ (beech) and $n=5$ (poplar). For ergosterol content, $n=3$. Values with the same small letter (beech) and capital letter (poplar) are not significantly different (Tukey HSD post hoc test)

decomposition process revealed significant differences between the two leaf species $\left(F_{1,56}=235.45\right.$, $P<0.001$, ANOVA).

The exponential breakdown coefficients $k_{\text {day }}$ was -0.0065 for beech and -0.0089 for poplar.
According to the classification of Petersen \& Cummins (1974), the exponential decay coefficients were intermediate for both species $\left(-0.01>k_{\text {day }}>\right.$ $-0.005)$, meaning that only resistant leaf material (e.g. petioles) would be present a year after submersion. Visible changes of the leaves occurred only in case of poplar leaves. After 42 days of submersion, we recognised distinctive fenestrate feeding patterns and other damages in poplar leaves, whereas beech leaves remained intact during the experimental time.

The ergosterol content (Fig. 3c) was significantly dependent on the exposition time in the lake $\left(F_{8,35}=\right.$ 46.52, $P<0.001$, ANOVA). The maximum concentration of ergosterol was $100.30 \mu \mathrm{g} \mathrm{g}^{-1} \mathrm{DW}$ after 28 days in beech and $142.05 \mu \mathrm{g} \mathrm{g}^{-1} \mathrm{DW}$ after 42 days in poplar (Fig. 3c). The correspondent biomass of hyphomycetes was $18.2 \mathrm{mg} \mathrm{g}^{-1} \mathrm{DW} \mathrm{mg}$ in beech and $25.8 \mathrm{mg}$ $\mathrm{g}^{-1} \mathrm{DW}$ in poplar. The decline of ergosterol concentrations after the peak time was not significant in both leaf species. Leaf type did not have an effect on the content of ergosterol $\left(F_{1,35}=2.51, P=0.121\right)$.

As leaf mass decreased in the litterbags, FPOM accumulated with progressing litter decomposition (Fig. 3d). The amount of FPOM was higher in poplar than in the beech litterbags, but differences were not significant $(U$-test: $Z=-0.156, P=0.606)$. Immediately after the storm events, the FPOM mass in the litterbags became reduced, but it increased afterwards (Fig. 3d).

At the beginning of the experiment, poplar leaves were significantly harder than beech leaves. In contrast to poplar leaves, which lost their leaf hardness rapidly after 27 days, the hardness of beech leaves did not decrease significantly during the first 42 days (Fig. 3b). Therefore, poplar leaves were significantly softer than beech at the end of the experiment. Two-way ANOVA revealed significant differences between beech and poplar leaves $\left(F_{1,56}=25.38, P<0.001\right)$. Leaves of both leaf species showed an increase of leaf hardness within the first 2 weeks.

\section{Benthic invertebrates}

Benthic invertebrate communities of the litterbags were clearly dominated by Orthocladiinae, while Caenis spec., Corynoneura spec., Chironominae and Dikerogammarus villosus were less abundant (Table 1). Numbers of individuals (mean \pm SD) and taxa increased quickly. After 27 days of leaf submersion, abundance (beech: $31.2 \pm 7.2$; poplar: 
Table 1 The 10 most common taxa in all litterbags of beech and poplar, without consideration of exposure time (mean $\pm \mathrm{SD}$ ), $n=32$ (beech) and $n=40$ (poplar)

\begin{tabular}{lcclc}
\hline Beech & & & Poplar & \\
\cline { 1 - 1 } \cline { 5 - 5 } Taxon & Mean \pm SD & & Taxon & Mean \pm SD \\
\hline Orthocladiinae & $41.3 \pm 59.06$ & & Orthocladiinae & $45.6 \pm 54.07$ \\
Caenis sp. & $5.8 \pm 7.97$ & & Caenis sp. & $4.7 \pm 6.74$ \\
Corynoneura sp. & $4.0 \pm 8.29$ & & D. villosus & $1.5 \pm 2.31$ \\
Chironominae & $2.4 \pm 4.78$ & & Chironominae & $1.5 \pm 3.58$ \\
Dikerogammarus villosus & $2.0 \pm 3.39$ & & Corynoneura sp. & $1.4 \pm 3.43$ \\
Gammarus sp. & $1.9 \pm 4.50$ & & Gammarus sp. & $1.1 \pm 3.16$ \\
Cladocera & $0.6 \pm 1.03$ & & Gammarus roeseli & $0.2 \pm 0.58$ \\
Gammarus roeseli & $0.6 \pm 1.30$ & & Tanypodinae & $0.2 \pm 0.46$ \\
Dreissena polymorpha & $0.3 \pm 1.05$ & & Cladocera & $0.2 \pm 0.45$ \\
Erpobdella sp. & $0.3 \pm 1.21$ & & Centroptilum sp. & $0.2 \pm 0.43$ \\
\hline
\end{tabular}

$42.0 \pm 11.2$ ) and number of taxa (beech: $5.6 \pm 0.9$; poplar: $4.5 \pm 1.5$ ) were on average values (Fig. 4). Litterbags of both tree species reached their maximum colonisation at the last sampling after 84 days (beech: $210 \pm 90$; poplar: $144 \pm 31$ ), i.e. a "saturation" effect could not be determined. This value (Fig. 3a, last value) is actually below the real situation, because at this date, a mass hatching of chironomid larvae, mainly Orthocladiinae, had taken place that were not quantitatively separated out of the FPOM mass as done before.

Number of taxa (Fig. 4b) also reached its maximum after 84 days with $8.4 \pm 0.4$ taxa (beech, mean number per litterbag $\pm \mathrm{SD}$ ) and $7.4 \pm 0.5$ (poplar). The exposure time of litterbags could be determined as a significant factor considering colonisation by invertebrates (Table 2). Both invertebrate density and number of taxa showed a decrease or lower increase during the periods of storm events. Comparisons between beech and poplar in terms of invertebrate density and number of taxa did not reveal significant differences ( $U$-test: invertebrate density: $Z=-0.15, P=0.881$; taxa: $Z=$ $-1.54, P=0.125)$. Neither could we find significant differences of species richness and eveness $(U$-test: richness: $Z=-1.92, P=0.055$; eveness: $Z=-1.63, P=$ $0.103)$ nor a correlation between taxon richness and exposure time (beech: $r=0.209, P=0.706$; poplar $r=$ $0.056, P=0.760)$. Nonmetric statistics underlined that the invertebrate community composition colonising the litterbags did not differ between the two leaf species, as visualised by the regular scattering of the symbols for beech and poplar samples in the nMDS plot (Fig. 5a, sampling dates pooled; ANOSIM: $R=$ $-0.008, P=0.601)$. However, we could observe a clear
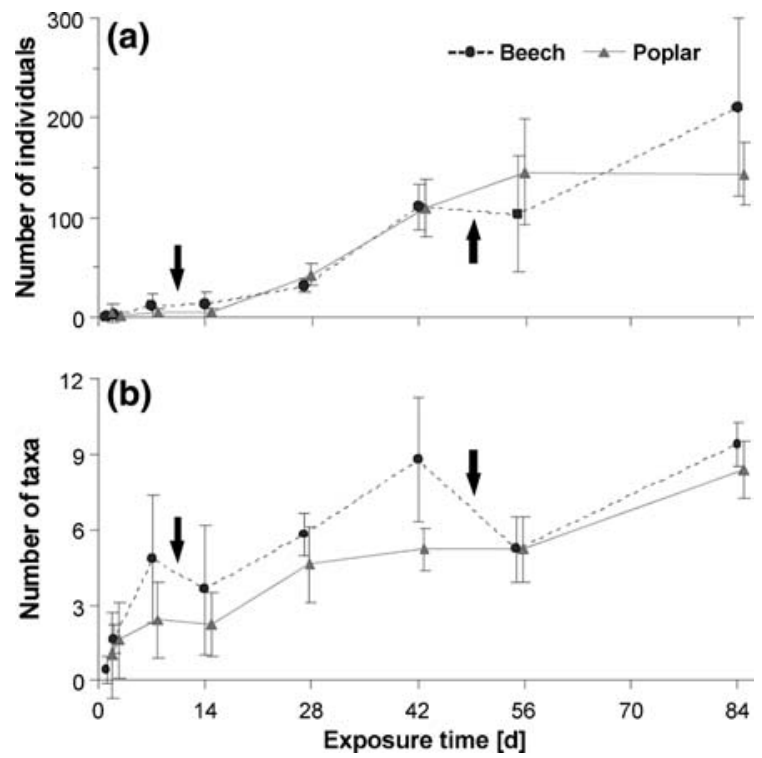

Fig. 4 Benthic invertebrate colonisation of litterbags over exposure time. (a) Mean abundance \pm SD. (b) Mean number of taxa $\pm \mathrm{SD}, n=35$ (beech) and $n=5$ (poplar). Arrows mark the two extraordinary incidents of storm events from NE directions

separation between sampling dates for both leaf species (Fig. 5b, c) (ANOSIM: beech: $R=0.67$, $P=0.001$; poplar: $R=0.568, P=0.001$ ) and a reduced variability between samples with increasing exposure time. This observation is supported by a negative correlation found between Pielous's eveness and exposure time (beech: $r=-0.691, P<0.001$; poplar $r=-0.534, P=0.002)$.

Contrary to our expectations, only few individuals of gammarids were detected in the litterbags. Most specimen occurred at the last sampling date, mainly 
Table 2 Results of Kruskal Wallis tests on number of indi viduals and taxa in litterbags of beech and poplar depending on exposure time

\begin{tabular}{llllllllll}
\hline & \multicolumn{3}{l}{ Beech } & & & \multicolumn{3}{l}{ Poplar } \\
\cline { 2 - 3 } & $\chi^{2}$ & df & $P$ & & $\chi^{2}$ & df & $P$ \\
\hline Number of individuals & 35.12 & 7 & $<0.001$ & 33.16 & 7 & $<0.001$ \\
Number of taxa & 29.60 & 7 & $<0.001$ & 28.94 & 7 & $<0.001$ \\
\hline
\end{tabular}
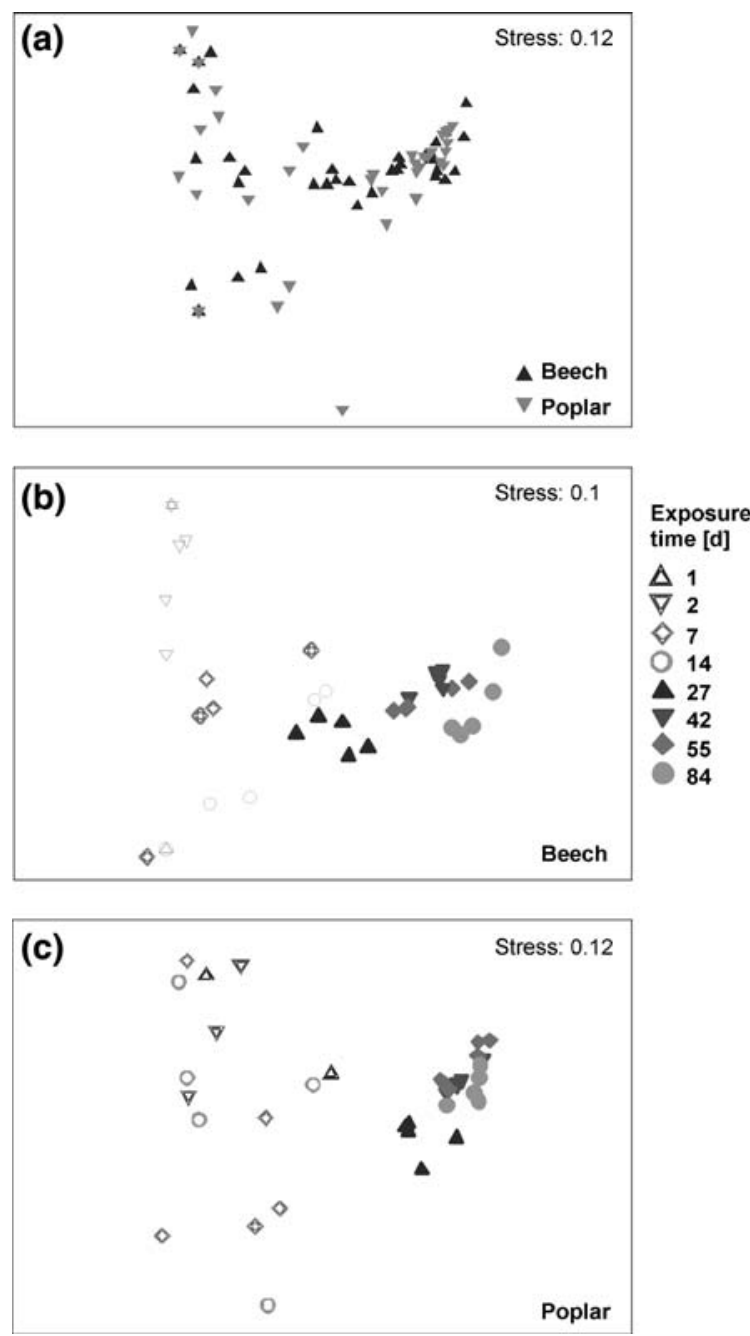

Fig. 5 nMDS plots of benthos community composition based on abundance data during the colonisation of beech and poplar litterbags grouped for all sampling dates (a) but differentiated between sampling dates in (b) for beech and (c) for poplar. The Bray Curtis similarity index was applied. Overlapping sym bols indicate identical benthic communities

very small Dikerogammarus villosus and very few individuals of Gammarus roeseli. Most other invertebrates were Orthocladiinae, Chironominae and
Corynoneura spec., which are scrapers and sediment/deposit feeders. Shredders were very scarce $(0$ $7.5 \%$ of the abundance of all individuals) and would have been even more scarce when excluding small gammarids $(<34 \mathrm{~mm})$ that are not supposed to be efficient shredders (Bohmann \& Tranvik, 2001). Shredding Trichoptera (Sericostoma spec., Mystacides spec., other Leptoceridae) appeared in very low abundances after 42 days of submersion of the leaves.

Wave mesocosm experiment

Maximum wave height in the wave mesocosm measured by ADV meter was $0.14 \mathrm{~m}$. The other abiotic factors were similar to that of the field experiment. The water was always saturated with oxygen. Mean water temperature in both mesocosms was $17.4^{\circ} \mathrm{C} \pm 3.2( \pm \mathrm{SD})$. The weight loss of the leaves was similar to the results from the field experiment; leaves of both species showed a rapid weight loss within the first $24 \mathrm{~h}$. Beach leaves lost about 5\% from initial dry weight in the wave mesocosm, but only $3.3 \%$ in the control; poplar lost 14 and $19 \%$, respectively (Fig. 6). Both exposition time and treatment were significant factors in terms of mass loss for poplar and beech (Table 3).

Hardness of beech leaves declined slowly in both mesocosms (Fig. 7). Leaf hardness reduction of poplar occurred especially between days 14 and 27. In contrast to treatment, exposure time was a significant factor for hardness of both beech and poplar leaves (Table 3). During the mesocosm experiment, some of the polar leaves in both mesocosm showed increasing "window" damages (roundish hollows in the leaves) that are indicative of benthic invertebrate shredding. In the control mesocosm, more leaves were affected than in the wave mesocosm. Further investigations revealed that a considerable number of benthic animals had colonised the mesocosms during the experiment, mainly Cladocera, Copepoda, Ostracoda, Baetidae and Orthocladiinae. None of these taxa are shredders; however, we cannot exclude that the activity of these scraping and deposit-feeding activity of invertebrates in the mesocosms at least partly influenced the mass loss of the leaves. Animal densities were not quantified, but they were clearly higher in the control mesocosm than in the wave mesocosm, giving a possible explanation for the increased weight loss of poplar leaves in the control mesocosm. 


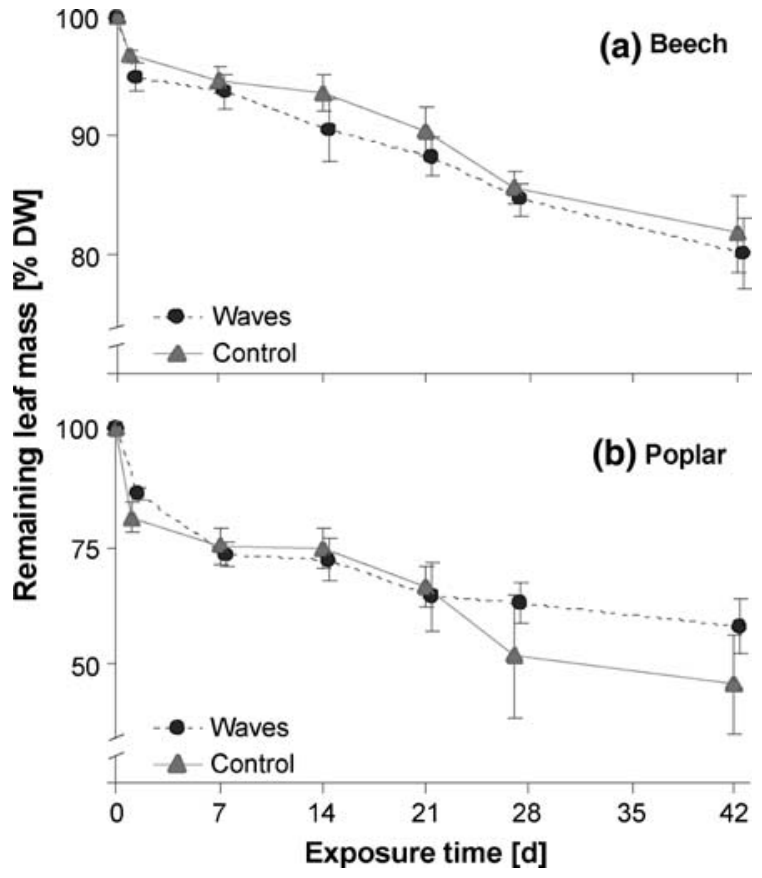

Fig. 6 Leaf degradation rate in remaining dry weight (\% DW $\pm \mathrm{SD}$ ) of beech (a) and poplar leaves (b) exposed in wave and control mesocosms at $0.4 \mathrm{~m}$ depth, $n=5$

\section{Discussion}

Importance of shredders

The decomposition rates of beech and poplar leaves were in the same magnitude in Lake Constance as recorded from leaf processing in streams (Gessner \&

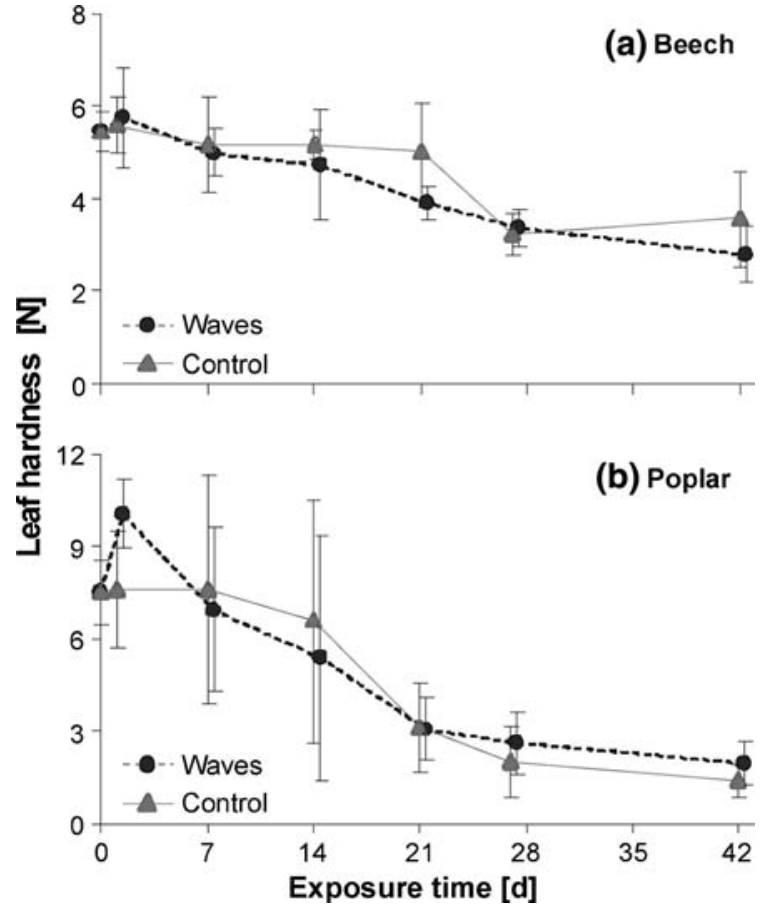

Fig. 7 Degradation rate of leaf hardness $(\mathrm{N} \pm \mathrm{SD})$ of beech (a) and poplar leaves (b) over exposure time in wave and control mesocosms at $0.4 \mathrm{~m}$ depth, $n=5$

Chauvet, 1994; Baldy et al., 1995; Menéndez et al., 2001). In contrast to the studies of Bjelke et al. (2005) and Bohman (2005) in mesotrophic lakes in Sweden, shredders were not abundant in the wave-impact zone of a pre-alpine lake during spring. We did not find preferences of the benthic invertebrates to one of the leaf types, as we expected from observations in
Table 3 Results of factorial ANOVA on mass loss and hardness of leaves depending on exposure time (Exp. Time), treatment (Treat.: Wave/Control) and interaction (Exp. $\times$ Treat.)

\begin{tabular}{llllrr}
\hline Variable & Species & Factor & $\mathrm{df}_{\text {eff, err }}$ & \multicolumn{1}{c}{$F$} & \multicolumn{1}{c}{$P$} \\
\hline Mass loss & \multirow{2}{*}{ Beech } & Exp. Time & 5,48 & 130.51 & $<0.001$ \\
& & Treatment & 1,48 & 16.75 & $<0.001$ \\
& & Exp. $\times$ Treat. & 5,48 & 1.40 & 0.243 \\
& \multirow{3}{*}{ Poplar } & Exp. Time & 5,48 & 72.42 & $<0.001$ \\
& & Treatment & 1,48 & 7.28 & 0.010 \\
& & Exp. $\times$ Treat. & 5,48 & 4.28 & 0.003 \\
Leaf hardness & Exp. Time & 5,48 & 18.10 & $<0.001$ \\
& \multirow{2}{*}{ Beech } & Treatment & 1,48 & 3.60 & 0.064 \\
& & Exp. $\times$ Treat. & 5,48 & 1.10 & 0.371 \\
& \multirow{2}{*}{ Poplar } & Exp. Time & 5,48 & 17.60 & $<0.001$ \\
& & Treatment & 1,48 & 0.95 & 0.335 \\
& & Exp. $\times$ Treat. & 5,48 & 0.59 & 0.709 \\
\hline
\end{tabular}


stream systems, where more recalcitrant leaf species were colonised later than leaf species with a more rapid decay (Petersen \& Cummins, 1974). However, beech as well as poplar are only of low "attractiveness" compared to other leaf types e.g. alder. Apparently, shredders did not play an important role in our experiment. Rather, our results imply that invertebrates might have used the exposed leaves not as a direct food source but as habitat (Pope et al., 1999; Dudgeon \& Wu, 1999).

Our observation that chironomids were the dominant species in decomposition experiments in lakes were made before by Oertli (1993) in Bois Vieux pond in western Switzerland and by Pope et al. (1999) in Scott lake (Ontario, Canada). According to the dominance of Chironomidae and to a lower extent Caenis spec. the most common functional feeding groups were scrapers and deposit feeders. We recognised no clear increase of shredders in the litterbags with progressing leaf decay, except for the small gammarids at the last sampling, probably originating from reproduction in spring. Further, typical biting marks of shredders were not observed on the exposed leaves of the field experiment.

Several reasons are possible to explain the low importance of shredders in our field study: (a) Phenology of the shredder species, (b) feeding preferences and alternative food sources for gammarids, (c) generally low abundance of the native gammarid species due to the recent occurrence of an invasive predator, (d) disturbance of shredder activity due to high wave impact and (e) relatively low food value and low palatability of the offered leaves.

(a) One possible reason for the unexpectedly low abundances of shredders in our litterbags is the season and low water temperatures. Many shredder species start their life cycle already in autumn during leaf fall and reach their maximum biomass during autumn and spring (Cummins et al., 1989; Bjelke, 2005). Earlier studies from the same site (Baumgärtner, 2004) documented that in Lake Constance, Gammarus roeseli has high biomass during winter and decreasing abundances until March. In spring, abundances increase due to reproduction, whereas biomass reaches a minimum in summer. Therefore, we expected an overlapping presence of large reproductive specimen and of small neonates during our study, which lasted from mid-February to June. Possibly, lower temperatures between mid-April and mid-May in 2005 (average $10^{\circ} \mathrm{C}$ ) compared with the same period of the years 2000 and $2001\left(151^{\circ}\right)$ reported in the earlier study (Baumgärtner, 2004) were responsible for the lower abundance of shredders.

(b) Further, invertebrates might rather feed on the algal growth on the leaf surfaces or on accumulated FPOM than on leaf tissue (Boulton \& Boon, 1991; Dangles et al., 2001). The amount of FPOM was approximately the same in litterbags of both leaf species and algae were observed on both species, giving support to this theory. At the beginning of primary production in spring, pelagic algae accumulate in the littoral near the shoreline due to wave action, and increase in importance as food source, which is also used by some shredder species (Bjelke, 2005). Shredders are rarely food specialists and may adapt their diet according to the current food offer (Friberg \& Jacobsen, 1994; Bjelke, 2005; Wantzen \& Wagner, 2006). This is especially true for gammarids (MacNeil et al., 1997). It is likely that during other periods of the year, for example, in autumn and early winter, when the leaves are freshly fallen and no algae are available as food source the activity of shredders might be distinctively more important than we observed.

(c) Shortly before our study began, a predatory gammarid from the pontocaspian area has invaded Lake Constance, Dikerogammarus villosus (Rey et al., 2005). In riverine catchments, it has already led to a dramatic decrease of the native fauna, especially other gammarid species (Dick et al., 2002). D. villosus causes a considerable impact on the native fauna in Lake Constance (Hesselschwerdt \& Wantzen, unpublished data).

(d) The specific abiotic conditions at our experimental site might be another factor responsible for the recorded low abundances of shredders. It is an erosional site with regular wave action and therefore very low deposition of leaves. Currents and waves regularly transport the leaf litter from the littoral to the shore line and accumulate it there. Especially, after storm events, we 
observed accumulations of litter above the shore line and probably large amounts of leaves are broken down there out of reach of aquatic shredders. We expect more shredder activity in other parts of Lake Constance, mainly in depositional sites where wave action and currents are low and leaves can sediment on the littoral ground. Our 'unwillingly' obtained results from the wave mesocosms (more benthic invertebrates and a higher weight loss of polar in the control mesocosm than in the wave mesocosm) support this hypothesis.

(e) Based upon the ergosterol values, the fungal biomass ranged between $3.7 \mathrm{mg} \mathrm{g}^{-1} \mathrm{DW}$ and 25.8 $\mathrm{mg}^{-1} \mathrm{DW}$ in the leaves. These values are relatively low compared to literature values from streams. Baldy et al. (1995) found $610 \mu \mathrm{g}$ Ergosterol g ${ }^{-1}$ AFDM in Populus nigra (approximately $8090 \mathrm{mg}$ biomass $\mathrm{g}^{-1} \mathrm{DW}$ ). For beech Gessner \& Chauvet (1994) measured $66 \mathrm{mg} \mathrm{g}^{-1}$ AFDM, (approximately $5055 \mathrm{mg}$ biomass $\mathrm{g}^{-1}$ DW). In a nutrient-rich stream, we found fungal biomass values as high as $55.5 \mathrm{mg} \mathrm{g}^{-1} \mathrm{DW}$ in beech. (Wantzen, unpublished data). Possibly, these low fungal biomass values and the known low palatability of poplar and beech leaves (Webster \& Benfield, 1986) reduced the attractiveness of the leaves as food for the shredders.

Importance of wave action

In the field experiment, the storm events strongly influenced the patterns of leaf weight loss, FPOM accumulation, leaf hardness (only poplar) and benthic invertebrate colonisation. In our study, the $k_{\mathrm{day}^{-}}$ value for beech $(-0.0065)$ was much higher than reported for another german lake with low wave impact, Lake Stechlin (-0.0011, Casper, 1987), indicating a high importance of wave action for litter degradation. The accelerated mass loss of both species in the litterbags during the first storm event (2nd week) was probably due to losses of leaf fragments that resulted from filling of the bags with air-dried leaves. We did not observe signs of decomposition of the leaves at either of the species at that time. However, only poplar leaves significantly lost weight during the second storm event (between days 42 and 55). At that date, poplar leaves were clearly decayed and fragmented, which was also discernable from the considerably reduced leaf hardness. We assume that shearing forces of waves were able to damage the softened leaves, remove soaked and macerated leaf tissue or to tear off whole pieces and transport them away. Even more distinctive was the effect of waves in case of FPOM, which was washed out of the litterbags during the storm events. Invertebrates were presumably washed away by the waves as well.

The mesocosm experiment revealed significant differences in leaf processing of beech leaves between treatment with and without waves. In the first $24 \mathrm{~h}$, beech leaves lost about $45 \%$ more of their dry weight with wave impact than in control mesocosm. We conclude that wave action primarily modified the leaching phase of beech leaves. In the case of poplar leaves, we found no such dependence on wave impact, although poplar leaves had a significantly higher leaching loss than beech in all experiments. Beech leaves are softer than poplar; their cuticule and waxy layer probably became damaged by the mechanical stress of the waves in our experiment, so that the leaching was promoted in wave mesocosm.

In our experiment, the poplar leaves became softer and susceptible to the shear forces only after several weeks of submersion in wave mesocosm. This result is in accordance with earlier studies on the maceration effects of microorganisms and/or invertebrates (Suberkropp \& Klug, 1980). Molinero et al. (1996) pointed out that hardness and robustness of leaves next to other factors can influence their proneness to abrasion and shear forces of wave action. They supposed that hydrodynamic forces especially increase the mass loss of soft leaves.

Contrary to our expectations, we observed no fragmentation of leaves in the mesocosms at all. Possibly, fragmentation only happens after a longer exposition time or when leaves are located directly in the zone of breakers as there are the most intensive turbulences. Under natural conditions, leaves in littoral are bundled off to the zone of breakers by waves and currents, and are ground there, or leaves on the beach are washed into the sublittoral zone by breakers (Merritt et al., 1984; Pieczyńska, 1986). 


\section{Conclusions and outlook}

This is the first study focussing on the effects of wave action on leaf processing in lakes. The results indicate that shredders did not have an import role in leaf processing in erosional sites of Lake Constance, where waves and currents prevent deposition of leaves. However, additional constraints on the shredder activity, such as phenology and impacts by exotic species, cannot be excluded. In the field experiment, strong waves during storm events had discernable effects on the decomposition process by removing leaf fragments, FPOM and invertebrates. In contrast to our expectations, the waves in the mesocosm experiment did not cause grinding of the leaves during a 42-day period. Our results imply to study the influence of wave action and shredders over longer periods of time (particularly in case of recalcitrant leaf species like beech) and to study leaf decay during different seasons at several sites with various sediment structures and exposition to waves. The influence of aquatic microbiota (fungi, bacteria) on physical degradation of the leaves and on shredder feeding was not analysed here but certainly deserves a closer examination in future studies.

Our field observations have shown an important impact of water-level fluctuations on the accessability of leaf litter by aquatic decomposers. Dry leaf litter that becomes blown into the littoral zone often becomes accumulated in the surf zone, where it becomes physically degraded by wave action and freezing. The continuous decrease of water level in winter leads to the development of banded deposition patterns of debris. In spring, these debris dams are important sites for aquatic and semi-aquatic detritivores, e.g. tipulids were observed to oviposit into the moist debris walls above the water line. During rising water levels in spring and early summer, this POM becomes transported back into the littoral zone, and the broken leaf particles are easily retained in the coarse sediments of the erosional sites. We conclude that leaf litter decomposition should not be regarded as a homogeneously distributed process that occurs in a similar way all over the lake. In analogy to rivers, we expect process domains (Montgomery, 1999) and biotic hot spots and hot moments (Wantzen \& Junk, 2006) in lakes, i.e. there are sites with different types of decomposition or storage of organic matter. Accordingly, we expect physical degradation to be high in erosional sites and low in depositional sites, while high biotic decomposition will occur in sites with intermediate hydraulic stress for invertebrate shredders and intermediate retention time for organic matter. Water-level fluctuations have a major impact on the temporal and spatial distribution of these process domains. At the same place, conditions may vary from erosional to depositional during periods of variable water levels. In pre-alpine lakes with variable sediments at different depth zones like Lake Constance, different water levels even decide over sediment composition, and thus physical and biotic elements of leaf litter decomposition.

\section{References}

Angradi, T. \& R. Hood, 1998. An application of the plaster dissolution method for quantifying water velocity in the shallow hyporheic zone of an Appalachian stream system. Freshwater Biology 39: 301315.

Baldy, V., M. O. Gessner \& E. Chauvet, 1995. Bacteria, fungi, and the breakdown of leaf litter in a large river. Oikos 74: 93102.

Bäuerle, E., D. Ollinger \& J. Ilmberger, 1998. Some meteo rological, hydrological, and hydrodynamical aspects of Upper Lake Constance. Archiv für Hydrobiologie Special Issues Advances in Limnology 53: 3183.

Baumgärtner, D., 2004. Principles of macroinvertebrate com munity structure in the littoral zone of Lake Constance. PhD Thesis, Universität Konstanz, Konstanz: 197 pp.

Bjelke, U., 2005. Species richness and functional diversity among lake living shredders: links to decomposition in littoral zones. PhD Thesis, University of Kalmar, Kalmar, Sweden: 35 pp.

Bjelke, U., I. M. Bohmann \& J. Hermann, 2005. Temporal niches of shredders in lake littorals with possible impli cations on ecosystem functioning. Aquatic Ecology 39: 4153.

Bohman, I., 2005. Coarse detritus in oligotrophic lake littoral zones utilization by invertebrates and contribution to carbon flow. PhD Thesis, University of Kalmar, Kalmar, Sweden: $37 \mathrm{pp}$.

Bohmann, I. M. \& J. Hermann, 2006. The timing of winter growing shredder species and leaf litter turnover rate in an oligotrophic lake, SE Sweden. Hydrobiologia 556: 99108.

Bohmann, I. M. \& L. J. Tranvik, 2001. The effects of shredding invertebrates on the transfer of organic carbon from lit toral leaf litter to water column bacteria. Aquatic Ecology 35: 4350 .

Boulton, A. J. \& P. I. Boon, 1991. A review of methodology used to measure leaf litter decomposition in lotic envi ronments: time to turn over an old leaf? Australian Journal of Marine \& Freshwater Research 42: 143.

Casper, P., 1987. Bedeutung von terrestrischem Pflanzenma terial für den Stoffhaushalt eines oligotrophen Gewässers (Stechlinsee). Limnologica 18: 423430. 
Casper, P., 1990. Input and mineralization of organic carbon in lakes. Archiv für Hydrobiologie Beiheft Ergebnisse der Limnologie 34: 131135.

Clarke, K. R. \& R. M. Warwick, 2001. Change in Marine Communities: An Approach to Statistical Analysis and Interpretation, 2nd edn. PRIMER E Ltd, Plymouth: 172 pp.

Cummins, K. W., M. A. Wilzbach, D. M. Gates, J. B. Perry \& W. B. Taliaferro, 1989. Shredders and riparian vegetation leaf litter that falls into streams influences communities of stream invertebrates. BioScience 39: 2430.

Dangles, O. \& F. Guérold, 1998. A comparative study of beech breakdown, energetic content, and associated fauna in acidic and non acidic streams. Archiv für Hydrobiologie 144: 2539.

Dangles, O., F. Guérold \& P. Usseglio Polatera, 2001. Role of transported particulate organic matter in the macroinver tebrate colonization of litterbags in streams. Freshwater Biology 46: 575586.

Dick, J. T. A., D. Platvoet \& D. W. Kelly, 2002. Predatory impact of the freshwater invader Dikerogammarus villo sus (Crustacea: Amphipoda). Canadian Journal of Fisheries \& Aquatic Sciences 59: 10781084.

Dudgeon, D. \& K. K. Y. Wu, 1999. Leaf litter in a tropical stream: food or substrate for macroinvertebrates? Archiv für Hydrobiologie 146: 6582.

Friberg, N. \& D. Jacobsen, 1994. Feeding plasticity of two detritivore shredders. Freshwater Biology 32: 133142.

Gasith, A. \& A. D. Hasler, 1976. Airborne litterfall as a source of organic matter in lakes. Limnology and Oceanography 21: 253258.

Gasith, A. \& W. Lawacz, 1976. Breakdown of leaf litter in the littoral zone of an eutrophic lake. Ekologia Polska 24: 421430.

Gessner, M. O., 2000. Breakdown and nutrient dynamics of submerged Phragmites shoots in the littoral zone of a temperate hardwater lake. Aquatic Botany 66: 920.

Gessner, M. O., 2005. Ergosterol as a measure of fungal bio mass. In Graça, M. A. S., F. Bärlocher \& M. O. Gessner (eds), Methods to Study Litter Decomposition A Prac tical Guide. Springer, Berlin: 189195.

Gessner, M. O. \& E. Chauvet, 1993. Ergosterol to biomass conversion factors for aquatic hyphomycetes. Applied and Environmental Microbiology 59: 502507.

Gessner, M. O. \& E. Chauvet, 1994. Importance of stream microfungi in controlling breakdown rates of leaf litter. Ecology 75: 18071817.

Gessner, M. O., E. Chauvet \& M. Dobson, 1999. A per spective on leaf litter breakdown in streams. Oikos 85 : 377384.

Gessner, M. O., B. Schieferstein, U. Mueller, S. Barkmann \& U. A. Lenfers, 1996. A partial budget of primary organic carbon flows in the littoral zone of a hardwater lake. Aquatic Botany 55: 93105.

Gessner, M. O. \& A. L. Schmitt, 1996. Use of solid phase extraction to determine ergosterol concentrations in plant tissue colonized by fungi. Applied and Environmental Microbiology 62: 415419.

Graça, M. A. S. \& M. Zimmer, 2005. Leaf toughness. In Graça, M. A. S., F. Bärlocher \& M. O. Gessner (eds), Methods to Study Litter Decomposition A Practical Guide. Springer, Berlin: 121125.
Grubbs, S. A. \& K. W. Cummins, 1996. Linkages between riparian forest composition and shredder voltinism. Ar chiv für Hydrobiologie 137: 3958.

IGKB Internationale Gewässerschutzkommission für den Bodensee (eds), 2004. Der Bodensee: Zustand Fakten Perspektiven. Bregenz: 176 pp.

Köhler, W., G. Schachtel \& P. Voleske, 1996. Biostatistik, 2nd edn. Springer, Berlin: 285 pp.

Kominkova, D., K. A. Kuehn, N. Busing, D. Steiner \& M. O. Gessner, 2000. Microbial biomass, growth, and respira tion associated with submerged litter of Phragmites australis decomposing in a littoral reed stand of a large lake. Aquatic Microbial Ecology 22: 271282.

Lozán, J. L. \& H. Kausch, 1998. Angewandte Statistik für Naturwissenschaftler, 2nd edn. Parey, Berlin: 287 pp.

Luft, G. \& H. Vieser, 1990. Veränderung der Bodensee Was serstände von 1887 bis 1987. Deutsche Gewässerkundliche Mitteilungen 34: 148156.

MacNeil, C., J. T. A. Dick \& R. W. Elwood, 1997. The trophic ecology of freshwater Gammarus spp., crustacea: amphi poda. problems and perspectives concerning the functional feeding group concept. Biological Reviews 72: 349364.

Menéndez, M., M. Martinez, O. Hernández \& F. A. Comín, 2001. Comparison of leaf decomposition in two Medi terranean rivers: a large eutrophic river and an oligotrophic stream (S Catalonia, NE Spain). International Review for Hydrobiology 86: 475486.

Merritt, R., K. W. Cummins \& T. M. Burton, 1984. The role of aquatic insects in the processing and cycling of nutrients. In Resh, V. H. \& D. M. Rosenberg (eds), The Ecology of Aquatic Insects. Praeger, New York: 134163.

Molinero, J., J. Pozo \& E. Gonzalez, 1996. Litter breakdown in streams of the Agüera catchment: influence of dis solved nutrients and land use. Freshwater Biology 36: 745756 .

Montgomery, D. R., 1999. Process domains and the river continuum. Journal of the American Water Resources Association 35: 397410.

Moog, O. (ed), 2002. Fauna Aquatica Austriaca, Lieferung 2002. Katalog zur autökologischen Einstufung aquatischer Organismen Österreichs. 2nd edn. Wasserwirtschaftskat aster, Bundesministerium für Land und Forstwirtschaft, Umwelt und Wasserwirtschaft, Wien.

Oertli, B., 1993. Leaf litter processing and energy flow through macroinvertebrates in a woodland pond (Switzerland). Oecologia 96: 466477.

Petersen, R. C. \& K. W. Cummins, 1974. Leaf processing in a woodland stream. Freshwater Biology 4: 343368.

Petticrew, E. L. \& J. Kalff, 1991. Calibration of a gypsum source for freshwater flow measurements. Canadian Journal of Fisheries and Aquatic Sciences 48: 12441249.

Pieczyńska, E., 1986. Sources and fate of detritus in the shore zone of lakes. Aquatic Botany 25: 153166.

Pope, R. J., A. M. Gordon \& N. K. Kaushik, 1999. Leaf litter colonization by invertebrates in the littoral zone of a small oligotrophic lake. Hydrobiologia 392: 99112.

Porter, E. T., L. P. Sanford \& S. E. Suttles, 2000. Gypsum dissolution is not an universal integrator of "water motion'. Limnology and Oceanography 45: 145158. 
Rey, P., U. Mürle, J. Ortlepp, M. Mörtl, N. Scheifhacken, S. Werner, W. Ostendorp \& J. Ostendorp, 2005. Wirbellose Neozoen im Bodensee neu eingeschleppte invasive Ben thos Arten Monitoringprogramm Bodenseeufer 2004. Landesanstalt für Umweltschutz, Langenargen: $44 \mathrm{pp}$.

Scheifhacken, N. 2006. Life at turbulent sites benthic com munities in lake littorals interacting with abiotic and biotic constraints. $\mathrm{PhD}$ thesis, University Constance, $197 \mathrm{pp}$.

Scheifhacken, N., C. Fiek \& K. O. Rothhaupt, 2007. Complex spatial and temporal patterns of littoral benthic commu nities interacting with water level fluctuations and wind exposure in the littoral zone of a large lake. Fundamental and Applied Limnology Archiv für Hydrobiologie 169(2): 115129.

Schmieder, K., B. Schunemann \& H. G. Schröder, 2004. Spatial patterns of surface sediment variables in the lit toral zone of Lake Constance (Germany). Archiv für Hydrobiologie 161: 455468.

Stoll, S., P. Klahold, N. Scheifhacken, H. Hofmann, K. O. Rothhaupt \& P. Fischer, 2008. Effects of water depth and hydrodynamics on the growth and distribution of juvenile cyprinids in the littoral zone of a large pre alpine lake. Journal of Fish Biology 72: 10011022.
Suberkropp, K. \& M. J. Klug, 1980. The maceration of deciduous leaf litter by aquatic hyphomycetes. Canadian Journal of Botany 58: 10251031.

Wallace, J. B., S. L. Eggert, J. L. Meyer \& J. R. Webster, 1997. Multiple trophic levels of a forest stream linked to ter restrial litter inputs. Science 277: 102104.

Wantzen, K. M. \& W. J. Junk, 2006. Aquatic terrestrial link ages from streams to rivers: biotic hot spots and hot moments. Archiv für Hydrobiologie Supplements (in press).

Wantzen, K. M. \& R. Wagner, 2006. Detritus processing by shredders: a tropical temperate comparison. Journal of the North American Benthological Society 25: 214230.

Wantzen, K. M., R. Wagner, R. Suetfeld \& W. J. Junk, 2002. How do plant herbivore interactions of trees influence coarse detritus processing by shredders in aquatic eco systems of different latitudes? Verhandlungen der Internationalen Vereinigung für Limnologie 28: 825821.

Webster, J. R., \& E. F. Benfield, 1986. Vascular plant break down in freshwater ecosystems. Annual Reviews in Ecology and Systematics 17: 567594. 